\title{
MUTYH as an Emerging Predictive Biomarker in Ovarian Cancer
}

\author{
Megan L. Hutchcraft ${ }^{1}$ (D), Holly H. Gallion ${ }^{1}$ and Jill M. Kolesar ${ }^{1,2, *(\mathbb{D})}$ \\ 1 Division of Gynecologic Oncology, Department of Obstetrics \& Gynecology, \\ University of Kentucky Markey Cancer Center, 800 Rose Street, Lexington, KY 40536-0263, USA; \\ megan.hutchcraft@uky.edu (M.L.H.); Holly.Gallion1@uky.edu (H.H.G.) \\ 2 Department of Pharmacy Practice \& Science, University of Kentucky College of Pharmacy, 567 Todd Building, \\ 789 South Limestone Street, Lexington, KY 40539-0596, USA \\ * Correspondence: jill.kolesar@uky.edu
}

Citation: Hutchcraft, M.L.; Gallion, H.H.; Kolesar, J.M. MUTYH as an Emerging Predictive Biomarker in Ovarian Cancer. Diagnostics 2021, 11, 84. https://doi.org/10.3390/ diagnostics11010084

Received: 6 December 2020 Accepted: 5 January 2021 Published: 6 January 2021

Publisher's Note: MDPI stays neutral with regard to jurisdictional clai$\mathrm{ms}$ in published maps and institutional affiliations.

Copyright: $\odot 2021$ by the authors. Licensee MDPI, Basel, Switzerland. This article is an open access article distributed under the terms and conditions of the Creative Commons Attribution (CC BY) license (https:// creativecommons.org/licenses/by/ $4.0 /)$.
Abstract: Approximately 18\% of ovarian cancers have an underlying genetic predisposition and many of the genetic alterations have become intervention and therapy targets. Although mutations in MutY homolog (MUTYH) are best known for MUTYH associated polyposis and colorectal cancer, it plays a role in the development of ovarian cancer. In this review, we discuss the function of the MUTYH gene, mutation epidemiology, and its mechanism for carcinogenesis. We additionally examine its emerging role in the development of ovarian cancer and how it may be used as a predictive and targetable biomarker. MUTYH mutations may confer the risk of ovarian cancer by the failure of its well-known base excision repair mechanism or by failure to induce cell death. Biallelic germline MUTYH mutations confer a $14 \%$ risk of ovarian cancer by age 70 . A monoallelic germline mutation in conjunction with a somatic MUTYH mutation may also contribute to the development of ovarian cancer. Resistance to platinum-based chemotherapeutic agents may be seen in tumors with monoallelic mutations, but platinum sensitivity in the biallelic setting. As MUTYH is intimately associated with targetable molecular partners, therapeutic options for MUTYH driven ovarian cancers include programed-death 1 /programed-death ligand- 1 inhibitors and poly-adenosine diphosphate ribose polymerase inhibitors. Understanding the function of $M U T Y H$ and its associated partners is critical for determining screening, risk reduction, and therapeutic approaches for MUTYH-driven ovarian cancers.

Keywords: MUTYH; ovarian cancer; predictive biomarker; base excision repair

\section{Introduction}

Ovarian cancer, which generally refers to cancers originating from the ovary, fallopian tube, and peritoneum, is the deadliest gynecologic cancer, responsible for taking the lives of approximately 14,000 women in the United States this year [1]. Although most ovarian cancers are sporadic, approximately $18 \%$ have an underlying genetic predisposition [2] The best known and most penetrant germline genetic mutations responsible for ovarian cancer are in the tumor suppressor breast cancer susceptibility genes 1 and 2 (BRCA1 and $B R C A 2)$, which are noted in 13-20\% of ovarian cancers [3,4]. These genes help maintain genome integrity by performing deoxyribonucleic acid (DNA) repair via the homologous recombination repair pathway [5]. BRCA1 and $B R C A 2(B R C A 1 / 2)$ mutations are inherited in an autosomal dominant fashion and contribute to an increased risk of several cancers including breast, ovarian, and pancreatic cancers [6]. BRCA1 carriers are estimated to have a $44 \%$ risk of developing ovarian cancer and a $72 \%$ risk of developing breast cancer by age 80 [7]. Similarly, BRCA2 carriers incur a $17 \%$ risk of developing ovarian cancer and a $69 \%$ risk of developing breast cancer by age 80 [7]. Evaluation of families with multiple cases of breast and/or ovarian cancer have demonstrated an approximate $40 \%$ mutation frequency 
in the $B R C A 1 / 2$ genes [8], suggesting less prevalent germline mutations contribute to the development of hereditary breast and ovarian cancer.

A germline mutation in the tumor protein 53 (TP53) tumor suppressor gene results in the rare, autosomal dominantly inherited Li Fraumeni hereditary cancer syndrome. Although Li Fraumeni syndrome has not classically been associated with an increased risk for ovarian cancer, higher than expected frequencies of ovarian cancer in patients with germline TP53 mutations have been reported [9]. Other gene mutations that confer ovarian cancer risk include those involved in the development of Lynch syndrome, or hereditary non-polyposis colorectal cancer. These include mutations in the mismatch repair genes mutL homolog 1 (MLH1), mutS homologs 2 and 6 (MSH2, MSH6), post-meiotic segregation increased 2 (PMS2), and epithelial cell adhesion molecule (EPCAM). Mutations in these genes are inherited in an autosomal dominant manner [10] and result in an increased risk of colon (lifetime risk 52-82\%), endometrial (lifetime risk 25-60\%), gastric (lifetime risk $6-13 \%$ ), and ovarian (lifetime risk 4-12\%) cancers [10]. Specifically, mutations in MLH1, MSH2, or MSH6 confer risk of ovarian cancer by age 75 of $10 \%, 17 \%$, or $13 \%$, respectively [11].

Germline mutations in the mutY homolog $(M U T Y H)$ base excision repair gene, is best known for their role in MUTYH-associated polyposis (MAP), an autosomal recessive condition that confers a $63 \%$ risk of colorectal cancer by age 60 [12]. Notably, although MAP is inherited in an autosomal recessive pattern, both monoallelic and biallelic MUTYH carriers are at an increased risk for other cancers (Table 1), including bladder, ovarian, duodenal, breast, gastric, hepatobiliary, endometrial, and skin cancers [13,14].

Table 1. Risk of cancer phenotypes for monoallelic and biallelic MUTYH pathogenic mutation carriers.

\begin{tabular}{|c|c|c|}
\hline Cancer Type & Risk in Monoallelic Carriers & Risk in Biallelic Carriers \\
\hline Colon Cancer & Possible increased risk & $63 \%^{1}$ \\
\hline Bladder Cancer & Insufficient evidence & $\begin{array}{l}25 \%^{2} \text { (males) } \\
8 \%{ }^{2} \text { (females) }\end{array}$ \\
\hline Ovarian Cancer & No increased risk & $14 \%^{2}$ (females) \\
\hline Duodenal Cancer & Insufficient evidence & $4 \%^{3}$ \\
\hline Breast Cancer & $11 \%^{1}$ (females) & $25 \%^{3}$ (females) \\
\hline Gastric Cancer & $\begin{array}{c}5 \%{ }^{1} \text { (males) } \\
2.3 \%^{1} \text { (females) }\end{array}$ & Insufficient evidence \\
\hline Hepatobiliary Cancer & $\begin{array}{c}3 \%{ }^{1} \text { (males) } \\
1.4 \%^{1} \text { (females) }\end{array}$ & Insufficient evidence \\
\hline Endometrial Cancer & $3 \%^{1}$ (females) & Possible increased risk \\
\hline Skin Cancer & No increased risk & Possible increased risk \\
\hline
\end{tabular}

${ }^{1}$ by age $60 ;{ }^{2}$ by age $70 ;{ }^{3}$ by age 75 .

The purpose of this article is to describe the role of MUTYH mutations in the pathogenesis of cancer and describe its emerging use in early detection, treatment decisions, and possible targeted therapies for ovarian cancer.

\section{MUTYH Gene}

\subsection{MUTYH Gene Function}

The MUTYH gene is located on the short arm of chromosome 1 (1p34.1) [15] and encodes instructions for the MYH glycosylase enzyme. This enzyme repairs DNA damage via a base excision repair mechanism. Many different carcinogens damage DNA, including reactive oxygen species, alkylating agents, DNA cross-linking agents, and radiation. Although MUTYH performs base excision repair and initiation of apoptosis in response to 
DNA damage from alkylation [16] and ultraviolet radiation [17], its primary function is to repair oxidative DNA damage [18].

Following stimulation from the MSH6 component of the MSH2/MSH6 heterodimer, MUTYH identifies and binds a mismatch of 8-hydroxyguanine (8-oxoG):A [19]. Myh glycosylase then excises the mismatched adenine, preventing inappropriate G:C > T:A transversions in subsequent rounds of DNA replication $[15,18,20,21]$. Removal of the inappropriate base-pairing generates an apurinic/apyrimidinic (AP) site [22]. A physical connection between MYH and AP endonuclease I (APE1) enables prompt action by APE1 to nick the DNA phosphodiester backbone, causing a single-strand DNA break [23] (Figure 1).

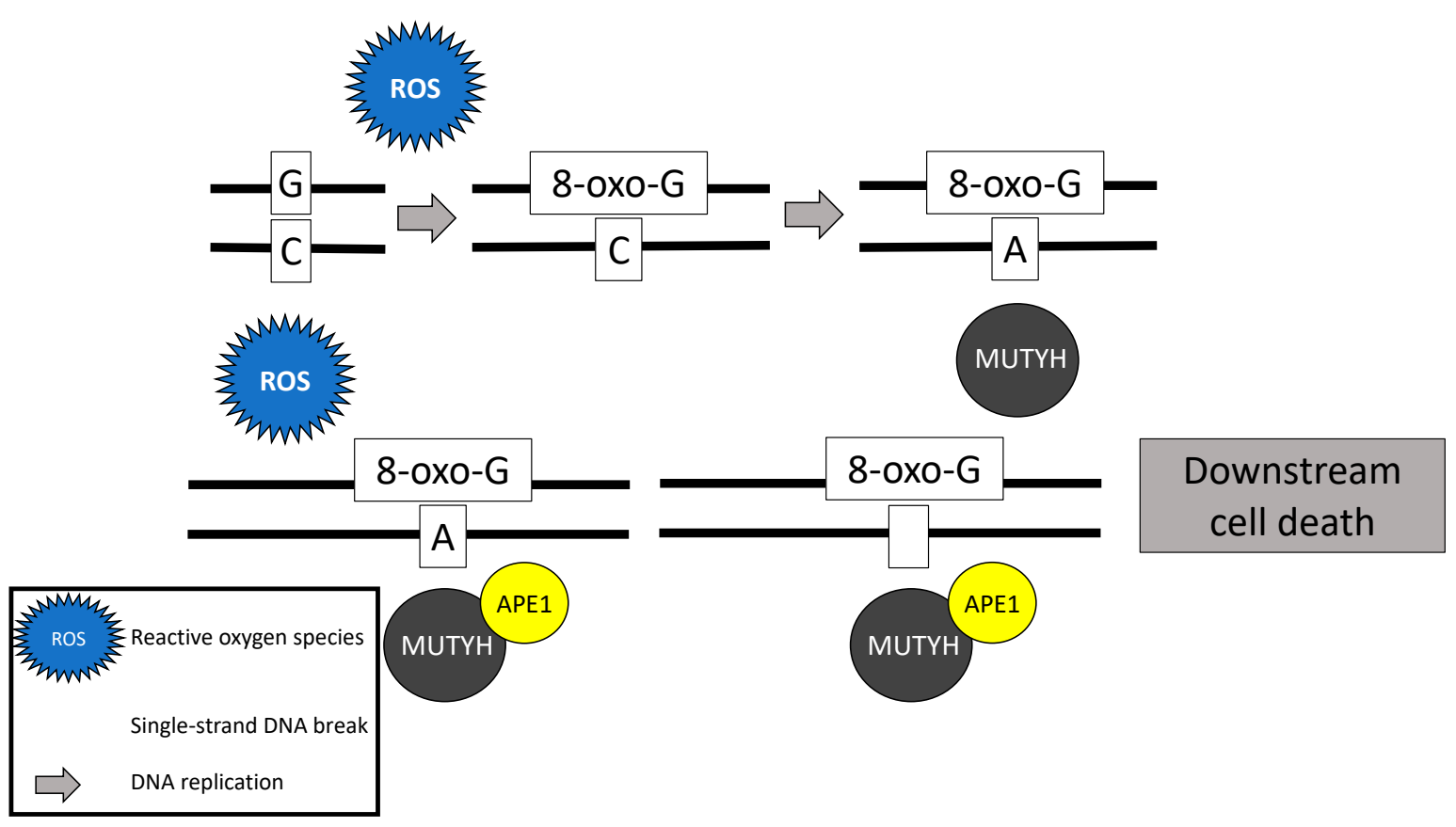

Figure 1. Base excision repair mechanism of the MutY homolog $(M U T Y H)$ in response to oxidative damage.

In addition to its well-known role in base excision repair, MUTYH also plays a role in rapid DNA damage response by inducing cell death $[21,24,25]$. Oka and colleagues (2008) demonstrated that single-strand mitochondrial DNA breaks performed by MYH's base excision repair mechanism result in cell death via calpain activation [25], which is a p53 independent process [24,25]. Alternatively, nuclear DNA breaks induced by MYH glycosylase result in cell death via a poly-adenosine diphosphate (ADP) ribose polymerase (PARP) signaling pathway [25], which is mediated by the tumor suppressor protein, p53 [24] and the mismatch repair gene MLH1 [26]. PARP senses and binds to single-strand DNA breaks, ribosylates itself and other cellular proteins, and signals apoptosis-inducing factor to translocate from the mitochondria to the nucleus, resulting in cell death [27].

Another method by which MUTYH responds to rapid DNA damage involves activation and phosphorylation of the tumor suppressor gene, checkpoint kinase 1 (CHEK1) via ataxia telangiectasia and rad3-related protein (ATR), another tumor suppressor gene [28,29]. When activated, CHEK1 activates cell cycle checkpoint processes prompting DNA repair and/or apoptosis [30]. Following exposure to DNA damaging agents, Hahm and colleagues (2011) found less CHEK1 and ATR phosphorylation in knockdown MUTYH cells than in wild-type cells [28]. When this pathway is altered, the activity of checkpoint kinase 2 (CHEK2) increases [28].

\subsection{MUTYH Germline Mutations}

The estimated prevalence of a heterozygous MUTYH germline mutation is 1-2\% [31,32] and homozygous germline mutations is $0.012 \%[33,34]$. Most pathogenic MUTYH muta- 
tions are missense [18,35], including Y179C (c.536A > G; previously Y165C (c.494A4G)) and G396D (c.1187G > A; previously G382D (c.1145G4A)). These mutations account for approximately $70 \%$ of all pathogenic mutations in Western populations [31,35] likely due to a genetic founder effect [21]. Although approximately $18 \%$ of all ovarian cancers are the result of an inherited predisposition [2], it is unknown how many of these ovarian cancers are directly attributable to biallelic MUTYH mutations. Consistent with the estimated prevalence of carrying a heterozygous $M U T Y H$ germline mutation [31,32], monoallelic germline MUTYH mutations have been identified in $1.9 \%$ of ovarian cancer patients [36].

\subsection{MUTYH Somatic Mutations}

Somatic MUTYH mutations are increasingly described in the literature and are noted to be present in 3.3\% of all tumors curated by the Catalogue of Somatic Mutations in Cancer (COSMIC) database [37]. Similar to germline mutations, most (56.7\%) mutations are missense. Over 400 different somatic MUTYH mutations have been curated by COSMIC and the most frequently identified is $\mathrm{c} 157+30 \mathrm{~A}>\mathrm{G}$, occurring $6 \%$ of the time [37]. Somatic MUTYH mutations have been described in sporadic colorectal cancer and may occur concurrent to somatic adenomatous polyposis coli (APC) gene mutations [38]. Furthermore, MUTYH somatic mutations have been described in Lynch syndrome patients and in patients whose tumors demonstrate mismatch repair deficiency but carry no mismatch repair germline mutation [39]. Outside of colon cancer, somatic MUTYH mutations have also been described in breast cancers [40,41] and in $0.24 \%$ of ovarian cancer samples [37].

\subsection{MUTYH Mutation and Mechanism for Oncogenesis}

While somatic and biallelic MUTYH mutations are associated with an increased risk of ovarian cancer, the majority of mechanistic studies have been performed in colon cancer model systems. Due to the critical role MUTYH plays in base excision repair, DNA with functional loss of MUTYH leads to an excess of 8-oxoguanine (8-oxo-G) which results in inappropriate G:C > T:A transversions in MAP colorectal tumors $[18,20,42]$ (Figure 2). Without active MUTYH activity, 8-oxoguanine glycosylase (OGG1), a DNA glycosylase enzyme involved in base excision repair, may identify and remove 8-oxo-G in an inappropriate 8-oxo-G:A pairing resulting in another mechanism for incorrect $\mathrm{G}: \mathrm{C}>$ T:A transversions; competition between MUTYH and OGG1 has demonstrated in a mouse model [21,43].
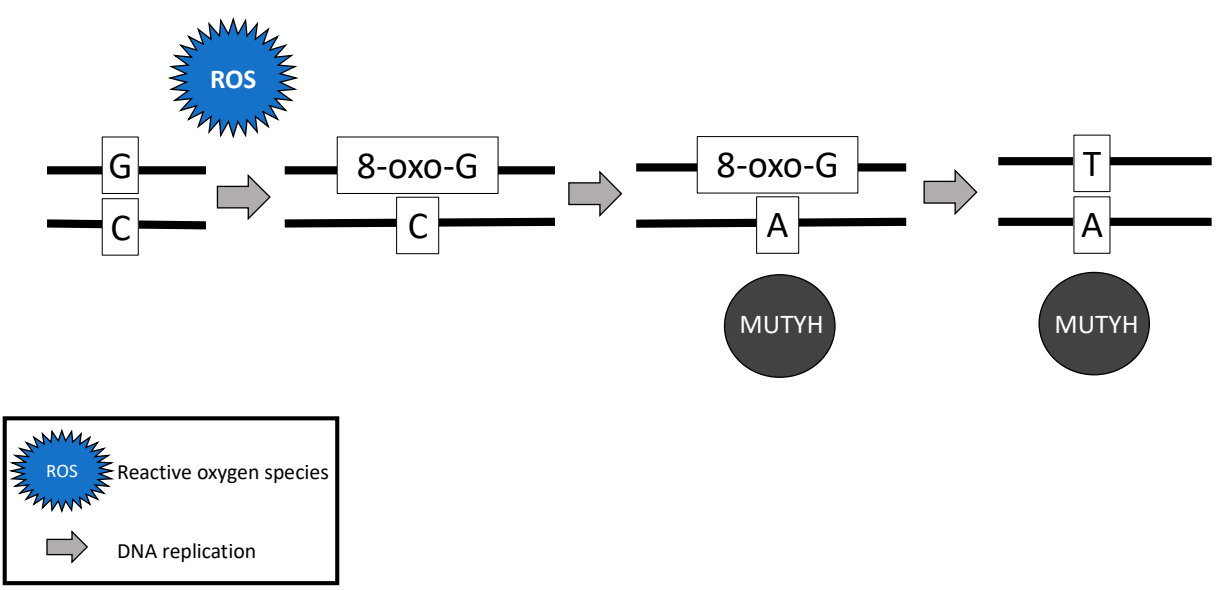

Figure 2. Failure of MUTYH's base excision repair mechanism and resultant $\mathrm{G}>\mathrm{T}$ transversion.

The somatic $\mathrm{G}>\mathrm{T}$ transversions seen in MAP tumors are likely the result of unrepaired DNA damage from reactive oxygen species [18]. Over time, increasing numbers of $\mathrm{G}>\mathrm{T}$ transversions in somatic tissues are likely to impact various oncogenes and tumor suppressor genes and lead to cancer [21,44,45]. For example, MAP colon tumors demonstrate a high prevalence of somatic APC [20,42] and Kirsten rat sarcoma $(K R A S)$ [42] G > T 
transversions. MAP colon tumors have also demonstrated somatic $\mathrm{G}>\mathrm{T}$ transversions in mismatch repair genes $M L H 1$ [46], MSH2, and MSH6 [47], resulting in microsatellite instability and mimicking Lynch syndrome [46,47].

In addition to carcinogenesis resulting from failed base excision repair, tumorigenesis may result from the failure of damaged cells to undergo apoptosis [24]. Oka and colleagues (2014) demonstrated that MUTYH knockdown colorectal cancer cells exposed to oxidative stress failed to undergo PARP-mediated apoptosis, resulting in aberrant cell growth and risk for tumorigenesis [24]. The tumor suppressor protein, p53 [26], regulates this process: the same aberrant cell growth was identified with either p53 deficiency or MUTYH knockout [24]. Although no studies have investigated the effect of mutant MUTYH in ovarian cancer cells, the mechanism for ovarian cancer oncogenesis is likely similar to that of colorectal cancer carcinogenesis as both of these cancers are established in the MAP phenotype. Furthermore, impaired MUTYH function in human keratinocyte HaCaT and human embryonic kidney HEK293 cells fail to phosphorylate ATR/CHEK1 [28]. Failure to prompt DNA repair and/or apoptosis [30] may shift cell checkpoint messages to CHEK2 control. Although there is significant overlap in CHEK1 and CHEK2 functions [28], without CHEK1 control, cells exposed to DNA damaging ionizing radiation fail to arrest in the G2 phase, leaving the possibility of survival and replication of damaged DNA and another potential mechanism for tumorigenesis [48]. Although these findings suggest carcinogenic plausibility, future research may test this hypothesis in ovarian cancer cell lines.

\section{Role of MUTYH in Ovarian Cancer}

\subsection{Ovarian Cancer Risk}

The genetic pathophysiology of ovarian cancer is complex. Kurman and Shih (2016) described common somatic genetic alterations driving ovarian cancer and these varied by histologic subtype [49]. For example, p53 pathway inactivation is common in high grade serous ovarian carcinomas, KRAS is implicated in mucinous and low grade serous ovarian carcinomas, and mismatch repair deficiency is involved in endometrioid ovarian carcinomas [49]. The MUTYH mutated ovarian tumors curated by COSMIC have demonstrated adenosquamous and serous histology; however, the sample size is limited [37]. Due to the multitude of DNA damage repair mechanisms controlled by MUTYH, it is reasonable to suspect that multiple ovarian cancer histologies may be associated with this alteration.

The risk for the development of ovarian cancer in patients with biallelic MUTYH germline mutations has been evaluated in two studies. In both studies, index cases were identified in patients with colon cancer who were enrolled in a cancer registry study and the association of MUTYH mutations with non-colonic tumors in affected family members was assessed. Among biallelic carriers, the risk of ovarian cancer was $10-14 \%$ by age 70 or $75[13,14]$. Monoallelic carriers did not demonstrate an increased risk of ovarian cancers, although numbers were relatively small and by design. all participants had a family history of colon cancer [13]. Minion and colleagues (2015) demonstrated $1.9 \%(9 / 466)$ of patients with ovarian cancer harbored a monoallelic MUTYH germline mutation [36], which is consistent with the estimated carrier rate [31-34]. It is possible that MUTYH carriers may progress to ovarian cancer if somatic MUTYH mutations co-occur, resulting in a homozygous somatic state, consistent with the well-established "two-hit hypothesis [50]. This combination of germline and somatic events was demonstrated by Thibodeau and colleagues (2019) and by Nones and colleagues (2019) in breast cancer patients $[40,41]$. Although COSMIC has identified somatic MUTYH mutations in $0.24 \%$ (3/1229) of curated ovarian cancers [37], many oncology practices only test ovarian cancer patients with next-generation sequencing for somatic $B R C A 1 / 2$ mutations or mismatch repair deficiency [51,52], suggesting this rate may be an underestimate.

MUTYH may contribute to the development of sporadic ovarian cancer via the welldescribed "incessant ovulation" hypothesis [53], "gonadotropin hypothesis" [54], or serous tubal intraepithelial carcinoma (STIC) hypothesis [55]. The "incessant ovulation" hypothesis suggests that more epithelial ovarian cell division during ovulation confers an 
increased opportunity for a somatic mutation predisposing to ovarian cancer [53,56]. MUTYH plays a more convincing role in the "gonadotropin hypothesis" paradigm. Pingariho and colleagues (2012) demonstrated that MUTYH may repair DNA damage induced by the carcinogenic metabolite glycinamide in human leukocytes [57] via base excision repair [58]. Glycinamide is the toxic metabolite of acrylamide, present in tobacco smoke and as a food and cosmetic contaminant [57]. Acrylamide is associated with increased follicle-stimulating hormone levels in premenopausal women [59], oxidative stress in rat gonads [60], and an increased risk of ovarian cancer [61]. More recently, p53 mutated lesions on fallopian tubal epithelium have been described as a precursor for many high grade serous ovarian cancers [62,63]. These STIC precancerous lesions were first described in BRCA1/2 mutated patients [62] and given the interaction between p53 and MUTYH, carcinogenesis via this pathway seems to be a possible mechanism in MUTYH patients; however, additional research is needed.

\subsection{Early Detection and Prevention of Ovarian Cancer}

As ovarian cancer screening programs have not demonstrated benefit for asymptomatic women [51,64], the best option for early detection and prevention of ovarian cancer is the identification of families and patients at risk. Women who carry a biallelic germline mutation may consider similar preventative measures as patients with other mutations that confer risk. Consistent with the "incessant ovulation" hypothesis of ovarian cancer pathogenesis, a decreased risk of ovarian cancer has been demonstrated in the BRCA1/2 mutated [65] and general populations [66] who have used oral contraceptives. This chemoprevention strategy may reduce the risk of ovarian cancer in populations with varying levels of pre-existing risk, including those with biallelic MUTYH germline mutations; however, prospective studies are needed.

The National Comprehensive Cancer Network recommends consideration of a riskreducing salpingo-oophorectomy for patients with certain germline mutations that predispose them to ovarian cancer [67]. The recommended timing of this procedure varies and is dependent on the time in which ovarian cancer presents with that specific mutation. Data regarding the utility of this procedure for patients with germline mutations other than $B R C A 1 / 2$ that confer ovarian cancer risk are insufficient and require a personalized approach [67]. Data suggest a lifetime risk of ovarian cancer in biallelic MUTYH mutation carriers approximates 14\% [13] and the median age of ovarian cancer diagnosis in this population is estimated at 51 years [14]. It seems reasonable to consider risk-reducing salpingo-oophorectomy for these patients at age $45-50$. The definitive timing of this procedure must be individualized and consider each patient's family history and risk factors. Although data are limited, patients with biallelic MUTYH mutations who are not yet ready for risk-reducing salpingo-oophorectomy (e.g., not yet completed childbearing or not yet ready for surgery) may undergo surveillance using a combination of serial transvaginal ultrasonography and serum cancer antigen 125 [68]. Additional studies with long-term follow-up are needed to determine the optimal surveillance protocol in this population.

\subsection{Chemotherapeutic Considerations}

Like many solid tumors, the majority of ovarian cancers require treatment with platinum-based chemotherapeutic agents [51]. The primary mechanism of action of platinum-based chemotherapeutics includes the creation of DNA-platinum adducts, leading to activation of DNA damage response system pathways, and ultimately cellular apoptosis $[69,70]$. Activated platinum reacts with purine DNA bases resulting in cross-linking of adjacent guanines. This DNA lesion is either repaired by one of the many DNA damage response mechanisms or deemed unrepairable prompting cellular apoptosis [70]. Although most ovarian cancer patients initially respond to platinum-taxane based chemotherapy, most recur, develop resistance, and endure a poor prognosis [51]. Platinum resistance mechanisms include: decreased intracellular accumulation, inactivation by glutathione, increased DNA repair, and failure of cells to undergo apoptosis [70]. 
As MUTYH mutations may drive some ovarian cancers, it is critical to anticipate how these tumors may respond to these therapies. Guo and colleagues (2019) demonstrated that esophageal squamous cell carcinoma cells with downregulated MUTYH activity contributed to cisplatin resistance via a Twist mediated epithelial-mesenchymal transition [71]. Similar to ovarian cancers, esophageal cancers are initially sensitive to upfront platinum-based chemotherapy; however, platinum resistance often ensues with continued treatment [71]. This similar treatment phenomenon suggests a similar mechanism could be involved in MUTYH-mutated ovarian cancers. Furthermore, tumors deficient in mismatch repair genes, including $M L H 1$ and $M S H 2$, are less likely to recognize DNA adducts and undergo apoptosis when exposed to cisplatin [72]. Because MUTYH's base excision repair mechanism functions in concert with the MSH2/MSH6 heterodimer [19], tumors deficient in MUTYH may demonstrate similar resistance to platinum-based agents. Although the scientific community is gaining an understanding of the importance of the epithelial-mesenchymal transition and other mechanisms of platinum resistance $[70,73]$, clinically possible methods to circumvent this problem have not been identified.

Although evidence suggests downregulated MUTYH activity may confer resistance to platinum-based chemotherapeutics, Jansson and coworkers (2013) demonstrated that Myh1/Rad1 homolog (Rad1) double mutant Schizosaccharomyces pombe (fission yeast) cells were more sensitive to cisplatin than either the Myh1 or Rad1 mutant alone [22]. Rad1, a tumor suppressor gene, is a component of the Rad9-Rad1-Hus1 complex, which senses DNA damage [74] and stimulates base excision repair [75]. Although studies investigating the response of human MUTYH mutant cells to various chemotherapeutic agents are lacking, the use of $S$. pombe cells may serve as a model to identify genomic markers of chemosensitivity or chemoresistance [76]. This model suggests that an isolated monoallelic MUTYH mutation may confer resistance to platinum-based chemotherapeutics; however, biallelic MUTYH mutations or a monoallelic MUTYH mutation that coincides with another DNA repair gene mutation may confer sensitivity. A similar phenomenon has been demonstrated in patients harboring germline $B R C A 1 / 2$ mutations. Ovarian cancer patients with germline $B R C A 1 / 2$ mutations are sensitive to platinum-based therapies and demonstrate improved survival [77]; however, if they develop a secondary somatic $B R C A 1 / 2$ mutation, platinum-resistance ensues [78].

Although alkylating agents are rarely used as first-line therapy for ovarian cancer, they may be used in salvage regimens [51]. Alkylating agents confer cytotoxicity by forming DNA crosslinks [69]. Fry et al. (2008) demonstrated MYH glycosylase activity in lymphoblastoid cells conferred sensitivity to alkylating agent N-methyl-N'-nitro-Nnitrosoguanidine and importantly determined that $\mathrm{MYH}$ knockout cells were resistant to this therapy and escaped cell death [16]. Evaluation of genomic predictors of cancer treatment efficacy and resistance often begins with lymphoblastoid cells [79]. This finding suggests that tumors with impaired MUTYH activity may be less responsive to alkylating chemotherapeutic agents; however, human studies are lacking to support this hypothesis.

\subsection{Potential Targeted Therapeutics}

In light of advancing knowledge about mechanisms for carcinogenesis and molecular pathways that drive the progression of cancers, significant advances have been made in developing targeted therapies for ovarian cancer. Although large clinical trials evaluating targeted MUTYH-therapies in ovarian cancer are unlikely, understanding the mechanisms involved in oncogenesis and successful treatments in other tumor types can help identify pathways that may be targeted with newer therapeutic agents (Figure 3). 


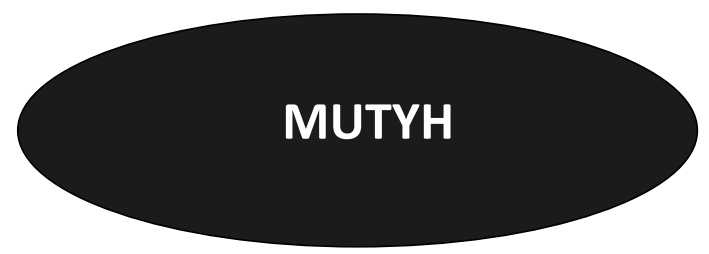

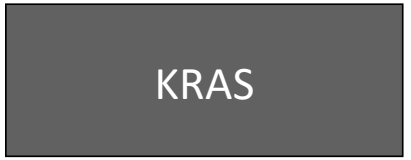

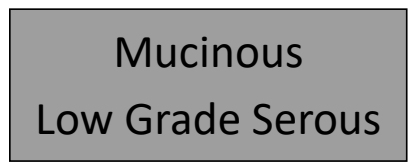

MEK inhibitors

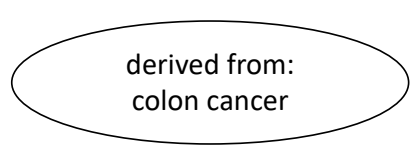

Microsatellite Instability

PD-1/PD-L1 Expression

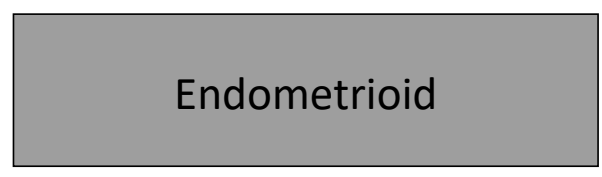

PD-1/PD-L1 Inhibitors

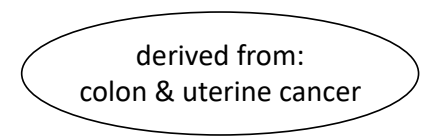

P53/PARP

CHEK1

High Grade Serous

PARP Inhibitors

derived from:

ovarian cancer \& pre-

clinical studies

Figure 3. Molecular aberrations, their associated histologic subtypes, potential targeted therapeutics, and origin of treatment considerations.

Like other microsatellite unstable tumors, which are common in those that harbor mismatch repair mutations, MAP colon tumors display signs of an active immune response [80]. This is not altogether unexpected given the intimate association between the MSH2 / MSH6 heterodimer and MUTYH. Furthermore, MAP tumors have demonstrated somatic G > T transversions in $M S H 2$ and microsatellite instability [47]. The presence of tumor-infiltrating lymphocytes in ovarian cancer is reported in tumors with endometrioid histology, mismatch repair deficiency, microsatellite instability, and increased expression of program death 1 (PD-1)/programed death ligand 1 (PD-L1) [81]. Tumors that demonstrate microsatellite instability or mismatch repair deficiency may be treated with immune checkpoint (PD-1/PD-L1) inhibitors [82]; however, not all microsatellite unstable tumors are responsive to this therapy [83]. Although a MUTYH mutation may not currently be a specific indication for the use of PD-1/PD-L1 inhibitors, Volkov and colleagues (2020) demonstrated a pronounced tumor response in a MAP colorectal cancer patient treated with this therapy [84]. We recommend performing immunohistochemistry for mismatch repair protein expression and/or PD-1/PD-L1 expression testing on tumors of patients with MUTYH germline mutations as evidence suggests tumors driven by MUTYH mutations may be responsive to PD-1/PD-L1 inhibitors [85].

Another potential targeted therapy for ovarian cancers resulting from MUTYH mutations includes PARP inhibitors. Much of the research on the role of PARP inhibitors in ovarian cancer have been undertaken on patients with $B R C A 1 / 2$ mutations and deficiencies in the homologous recombination repair pathway [5]. CHEK1 is a tumor suppressor involved in the homologous recombination repair pathway [86] and is activated and phosphorylated by MUTYH in response to DNA damage [28]. Even though the primary role of MUTYH is to maintain DNA integrity via base excision repair, it seems to play at least an indirect role in homologous recombination repair. CHEK1 mutations have conferred susceptibility to PARP-inhibitors due to its role in homologous recombination repair [87]. Furthermore, results from the PRIMA/ENGOT-OV26/GOG-3012 trial demonstrated niraparib efficacy for $B R C A 1 / 2$ wildtype patients and patients with intact homologous recombination repair in addition to efficacy for $B R C A 1 / 2$ mutated and homologous recombination repair-deficient ovarian cancer patients [88]. We hypothesize the benefit of PARP 
inhibition may be similar to those with homologous recombination repair deficiency and should be considered in this population.

KRAS G:T transversions are common in MAP tumors and the success of colorectal cancer treatment options depends on KRAS mutational status [89,90]. Although a KRAS mutation confers resistance to panitumumab, a human monoclonal antibody against epidermal growth factor receptor in colorectal cancer [89], oncogenic KRAS mutations may be sensitive to mitogen-activated protein kinase kinase (MEK) inhibitors in other solid tumors [91], including ovarian cancer [92]. Although none of these inhibitors are currently available for use in ovarian cancer outside of a clinical trial, many are under investigation and may be options in the near future [93]. We anticipate that as we learn more about MEK inhibitor usage in ovarian cancer, somatic testing for this gene, especially in patients with MUTYH germline mutations, may aid treatment decisions as it does in colorectal cancer [90].

\section{Conclusions}

Biallelic MUTYH mutation is associated with an increased risk of ovarian cancer. Understanding the function of MUTYH and its associated partners is critical for determining screening, risk reduction, and therapeutic approaches for $M U T Y H$-driven ovarian cancers. Much of the existing literature on MUTYH function comes from colorectal cancer; however, this data provides foundational information that is critical for understanding its role in ovarian cancer. Although tumors driven by MUTYH may be resistant to common chemotherapeutic approaches, including platinum-based agents and alkylating agents, the role of PD-1/PD-L1 inhibitors and PARP inhibitors in these tumors seems promising.

Author Contributions: Conceptualization, M.L.H. and J.M.K.; investigation, M.L.H. and J.M.K.; resources, J.M.K.; data curation, M.L.H.; writing—original draft preparation, M.L.H.; writingreview and editing, M.L.H., H.H.G., and J.M.K.; visualization, M.L.H.; supervision, H.H.G. and J.M.K.; project administration, J.M.K.; funding acquisition, J.M.K. All authors have read and agreed to the published version of the manuscript.

Funding: This research received no external funding.

Institutional Review Board Statement: This review was an analysis of publicly available data and was exempt from institutional review board review at the University of Kentucky.

Informed Consent Statement: Informed consent was not applicable as no humans were studies for this review.

Data Availability Statement: No new data were created or analyzed in this study. Data sharing is not applicable to this article.

Conflicts of Interest: The authors declare no conflict of interest.

\section{References}

1. National Cancer Institute: Surveillance, Epidemiology, and End Results Program. Cancer Stat Facts: Ovarian Cancer. Available online: https: / / seer.cancer.gov/statfacts/html/ovary.html (accessed on 26 August 2020).

2. Norquist, B.M.; Harrell, M.I.; Brady, M.F.; Walsh, T.; Lee, M.K.; Gulsuner, S.; Bernards, S.S.; Casadei, S.; Yi, Q.; Burger, R.A.; et al Inherited mutations in women with ovarian carcinoma. JAMA Oncol. 2016, 2, 482-490. [CrossRef] [PubMed]

3. Zhang, S.; Royer, R.; Li, S.; McLaughlin, J.R.; Rosen, B.; Risch, H.A.; Fan, I.; Bradley, L.; Shaw, P.A.; Narod, S.A. Frequencies of BRCA1 and BRCA2 mutations among 1342 unselected patients with invasive ovarian cancer. Gynecol. Oncol. 2011, 121, 353-357. [CrossRef] [PubMed]

4. Schrader, K.A.; Hurlburt, J.; Kalloger, S.E.; Hansford, S.; Young, S.; Huntsman, D.G.; Gilks, C.B.; McAlpine, J.N. Germline BRCA1 and BRCA2 mutations in ovarian cancer: Utility of a histology-based referral strategy. Obstet. Gynecol. 2012, 120, 235-240. [CrossRef] [PubMed]

5. Faraoni, I.; Graziani, G. Role of BRCA mutations in cancer treatment with poly(ADP-ribose) polymerase (PARP) inhibitors. Cancers 2018, 10, 487. [CrossRef]

6. Hu, C.; Hart, S.N.; Polley, E.C.; Gnanaolivu, R.; Shimelis, H.; Lee, K.Y.; Lilyquist, J.; Na, J.; Moore, R.; Antwi, S.O.; et al. Association between inherited germline mutations in cancer predisposition genes and risk of pancreatic cancer. JAMA 2018, 319, 2401-2409. [CrossRef] 
7. Kuchenbaecker, K.B.; Hopper, J.L.; Barnes, D.R.; Phillips, K.A.; Mooij, T.M.; Roos-Blom, M.J.; Jervis, S.; van Leeuwen, F.E.; Milne, R.L.; Andrieu, N.; et al. Risks of breast, ovarian, and contralateral breast cancer for BRCA1 and BRCA2 mutation carriers. JAMA 2017, 317, 2402-2416. [CrossRef]

8. Kast, K.; Rhiem, K.; Wappenschmidt, B.; Hahnen, E.; Hauke, J.; Bluemcke, B.; Zarghooni, V.; Herold, N.; Ditsch, N.; Kiechle, M.; et al. Prevalence of BRCA1/2 germline mutations in 21401 families with breast and ovarian cancer. J. Med. Genet. 2016, 53, 465-471. [CrossRef]

9. Gonzalez, K.D.; Noltner, K.A.; Buzin, C.H.; Gu, D.; Wen-Fong, C.Y.; Nguyen, V.Q.; Han, J.H.; Lowstuter, K.; Longmate, J.; Sommer, S.S.; et al. Beyond Li Fraumeni Syndrome: Clinical characteristics of families with p53 germline mutations. J. Clin. Oncol. 2009, 27, 1250-1256. [CrossRef]

10. Kohlmann, W.; Gruber, S.B. Lynch syndrome. In GeneReviews [Internet]; [Updated 2018]; Adam, M.P., Ardinger, H.H., Pagon, R.A., Wallace, S.E., Eds.; University of Washington: Seattle, WA, USA, 2004. Available online: https://www.ncbi.nlm.nih.gov/books/ NBK1211/ (accessed on 25 August 2020).

11. Møller, P.; Seppälä, T.T.; Bernstein, I.; Holinski-Feder, E.; Sala, P.; Gareth Evans, D.; Lindblom, A.; Macrae, F.; Blanco, I.; Sijmons, R.H.; et al. Cancer risk and survival in path_MMR carriers by gene and gender up to 75 years of age: A report from the Prospective Lynch Syndrome Database. Gut 2018, 67, 1306-1316, Corrected in Gut 2020, 69, e4. [CrossRef]

12. Nieuwenhuis, M.H.; Vogt, S.; Jones, N.; Nielsen, M.; Hes, F.J.; Sampson, J.R.; Aretz, S.; Vasen, H.F. Evidence for accelerated colorectal adenoma-carcinoma progression in MUTYH-associated polyposis? Gut 2012, 61, 734-738. [CrossRef]

13. Win, A.K.; Reece, J.C.; Dowty, J.G.; Buchanan, D.D.; Clendenning, M.; Rosty, C.; Southey, M.C.; Young, J.P.; Cleary, S.P.; Kim, H.; et al. Risk of extracolonic cancers for people with biallelic and monoallelic mutations in MUTYH. Int. J. Cancer 2016, 139, 1557-1563. [CrossRef] [PubMed]

14. Vogt, S.; Jones, N.; Christian, D.; Engel, C.; Nielsen, M.; Kaufmann, A.; Steinke, V.; Vasen, H.F.; Propping, P.; Sampson, J.R.; et al. Expanded extracolonic tumor spectrum in MUTYH-associated polyposis. Gastroenterology 2009, 137, 1976-1985.e10. [CrossRef] [PubMed]

15. United States National Library of Medicine. MUTYH Gene. Available online: https://medlineplus.gov/genetics/gene/mutyh/ (accessed on 28 July 2020).

16. Fry, R.C.; Svensson, J.P.; Valiathan, C.; Wang, E.; Hogan, B.J.; Bhattacharya, S.; Bugni, J.M.; Whittaker, C.A.; Samson, L.D. Genomic predictors of interindividual differences in response to DNA damaging agents. Genes Dev. 2008, 22, 2621-2626. [CrossRef] [PubMed]

17. Mazouzi, A.; Battistini, F.; Moser, S.C.; Ferreira da Silva, J.; Wiedner, M.; Owusu, M.; Lardeau, C.H.; Ringler, A.; Weil, B.; Neesen, J.; et al. Repair of UV-induced DNA damage independent of nucleotide excision repair is masked by MUTYH. Mol. Cell 2017, 68, 797-807.e7. [CrossRef] [PubMed]

18. Molatore, S.; Russo, M.T.; D’Agostino, V.G.; Barone, F.; Matsumoto, Y.; Albertini, A.M.; Minoprio, A.; Degan, P.; Mazzei, F.; Bignami, M.; et al. MUTYH mutations associated with familial adenomatous polyposis: Functional characterization by a mammalian cell-based assay. Hum. Mutat. 2010, 31, 159-166. [CrossRef] [PubMed]

19. Gu, Y.; Parker, A.; Wilson, T.M.; Bai, H.; Chang, D.Y.; Lu, A.L. Human MutY homolog, a DNA glycosylase involved in base excision repair, physically and functionally interacts with mismatch repair proteins human MutS homolog 2/human MutS homolog 6. J. Biol. Chem. 2002, 277, 11135-11142. [CrossRef]

20. Al-Tassan, N.; Chmiel, N.H.; Maynard, J.; Fleming, N.; Livingston, A.L.; Williams, G.T.; Hodges, A.K.; Davies, D.R.; David, S.S.; Sampson, J.R.; et al. Inherited variants of MYH associated with somatic G:C->T:A mutations in colorectal tumors. Nat. Genet. 2002, 30, 227-232. [CrossRef] [PubMed]

21. Raetz, A.G.; David, S.S. When you're strange: Unusual features of the MUTYH glycosylase and implications in cancer. DNA Repair 2019, 80, 16-25. [CrossRef] [PubMed]

22. Jansson, K.; Alao, J.P.; Viktorsson, K.; Warringer, J.; Lewensohn, R.; Sunnerhagen, P. A role for Myh1 in DNA repair after treatment with strand-breaking and crosslinking chemotherapeutic agents. Environ. Mol. Mutagen. 2013, 54, 327-337. [CrossRef]

23. Luncsford, P.J.; Manvilla, B.A.; Patterson, D.N.; Malik, S.S.; Jin, J.; Hwang, B.J.; Gunther, R.; Kalvakolanu, S.; Lipinski, L.J.; Yuan, W.; et al. Coordination of MYH DNA glycosylase and APE1 endonuclease activities via physical interactions. DNA Repair 2013, 12, 1043-1052. [CrossRef]

24. Oka, S.; Leon, J.; Tsuchimoto, D.; Sakumi, K.; Nakabeppu, Y. MUTYH, an adenine DNA glycosylase, mediates p53 tumor suppression via PARP-dependent cell death. Oncogenesis 2014, 3, e121, Erratum in Oncogenesis 2015, 4, e142. [CrossRef] [PubMed]

25. Oka, S.; Ohno, M.; Tsuchimoto, D.; Sakumi, K.; Furuichi, M.; Nakabeppu, Y. Two distinct pathways of cell death triggered by oxidative damage to nuclear and mitochondrial DNAs. EMBO J. 2008, 27, 421-432. [CrossRef] [PubMed]

26. McDaid, J.R.; Loughery, J.; Dunne, P.; Boyer, J.C.; Downes, C.S.; Farber, R.A.; Walsh, C.P. MLH1 mediates PARP-dependent cell death in response to the methylating agent N-methyl-N-nitrosourea. Br. J. Cancer 2009, 101, 441-451. [CrossRef]

27. Fatokun, A.A.; Dawson, V.L.; Dawson, T.M. Parthanatos: Mitochondrial-linked mechanisms and therapeutic opportunities. Br. J. Pharmacol. 2014, 171, 2000-2016. [CrossRef] [PubMed]

28. Hahm, S.H.; Park, J.H.; Ko, S.I.; Lee, Y.R.; Chung, I.S.; Chung, J.H.; Kang, L.W.; Han, Y.S. Knock-down of human MutY homolog (hMYH) decreases phosphorylation of checkpoint kinase 1 (Chk1) induced by hydroxyurea and UV treatment. BMB Rep. 2011, 44, 352-357. [CrossRef] 
29. Zhao, H.; Piwnica-Worms, H. ATR-mediated checkpoint pathways regulate phosphorylation and activation of human Chk1. Mol. Cell Biol. 2001, 21, 4129-4139. [CrossRef]

30. Patil, M.; Pabla, N.; Dong, Z. Checkpoint kinase 1 in DNA damage response and cell cycle regulation. Cell Mol. Life Sci. 2013, 70, 4009-4021. [CrossRef]

31. Nielsen, M.; Infante, E.; Brand, R. MUTYH polyposis. In GeneReviews [Internet]; [Updated 2019]; Adam, M.P., Ardinger, H.H., Pagon, R.A., Wallace, S.E., Eds.; University of Washington: Seattle, WA, USA, 2012. Available online: https://www.ncbi.nlm.nih. gov/books/NBK107219/\# (accessed on 30 July 2020).

32. Samadder, N.J.; Riegert-Johnson, D.; Boardman, L.; Rhodes, D.; Wick, M.; Okuno, S.; Kunze, K.L.; Golafshar, M.; Uson, P.L.S.; Mountjoy, L.; et al. Comparison of universal genetic testing vs guideline-directed targeted testing for patients with hereditary cancer syndrome. JAMA Oncol. 2020. [CrossRef]

33. Win, A.K.; Hopper, J.L.; Jenkins, M.A. Association between monoallelic MUTYH mutation and colorectal cancer risk: A metaregression analysis. Fam. Cancer 2011, 10,1-9. [CrossRef]

34. Win, A.K.; Jenkins, M.A.; Dowty, J.G.; Antoniou, A.C.; Lee, A.; Giles, G.G.; Buchanan, D.D.; Clendenning, M.; Rosty, C.; Ahnen, D.J.; et al. Prevalence and penetrance of major genes and polygenes for colorectal cancer. Cancer Epidemiol. Biomark. Prev. 2017, 26, 404-412. [CrossRef]

35. Cheadle, J.P.; Sampson, J.R. MUTYH-associated polyposis-from defect in base excision repair to clinical genetic testing. DNA Repair 2007, 6, 274-279. [CrossRef] [PubMed]

36. Minion, L.E.; Dolinsky, J.S.; Chase, D.M.; Dunlop, C.L.; Chao, E.C.; Monk, B.J. Hereditary predisposition to ovarian cancer, looking beyond BRCA1/BRCA2. Gynecol. Oncol. 2015, 137, 86-92. [CrossRef] [PubMed]

37. Catalogue of Somatic Mutations in Cancer (COSMIC): MUTYH Gene. Available online: https://cancer.sanger.ac.uk/cosmic/ gene/analysis?ln=MUTYH (accessed on 25 August 2020).

38. Bougatef, K.; Marrakchi, R.; Kourda, N.; Ben Lahely, Y.B.; Jileni, S.B.; El Khil, H.K.; Soubrier, F.; Ben Ammar Elgaaied, A. Somatic mutation of MutYH in Tunisian patients with sporadic colorectal cancer. J. Clin. Lab. Anal. 2007, 21, 372-374. [CrossRef] [PubMed]

39. Vargas-Parra, G.M.; Gonzalez-Acosta, M.; Thompson, B.A.; Gomez, C.; Fernandez, A.; Damaso, E.; Pons, T.; Morak, M.; Del Valle, J.; Iglesias, S.; et al. Elucidating the molecular basis of MSH2-deficient tumors by combined germline and somatic analysis. Int. J. Cancer 2017, 141, 1365-1380. [CrossRef] [PubMed]

40. Thibodeau, M.L.; Zhao, E.Y.; Reisle, C.; Ch'ng, C.; Wong, H.L.; Shen, Y.; Jones, M.R.; Lim, H.J.; Young, S.; Cremin, C.; et al. Base excision repair deficiency signatures implicate germline and somatic MUTYH aberrations in pancreatic ductal adenocarcinoma and breast cancer oncogenesis. Cold Spring Harb. Mol. Case Stud. 2019, 5. [CrossRef] [PubMed]

41. Nones, K.; Johnson, J.; Newell, F.; Patch, A.M.; Thorne, H.; Kazakoff, S.H.; de Luca, X.M.; Parsons, M.T.; Ferguson, K.; Reid, L.E.; et al. Whole-genome sequencing reveals clinically relevant insights into the aetiology of familial breast cancers. Ann. Oncol. 2019, 30, 1071-1079. [CrossRef] [PubMed]

42. Viel, A.; Bruselles, A.; Meccia, E.; Fornasarig, M.; Quaia, M.; Canzonieri, V.; Policicchio, E.; Urso, E.D.; Agostini, M.; Genuardi, M.; et al. A specific mutational signature associated with DNA 8-oxoguanine persistence in MUTYH-defective colorectal cancer. EBioMedicine 2017, 20, 39-49. [CrossRef]

43. Tominaga, Y.; Ushijima, Y.; Tsuchimoto, D.; Mishima, M.; Shirakawa, M.; Hirano, S.; Sakumi, K.; Nakabeppu, Y. MUTYH prevents OGG1 or APEX1 from inappropriately processing its substrate or reaction product with its C-terminal domain. Nucleic Acids Res. 2004, 32, 3198-3211. [CrossRef]

44. Rashid, M.; Fischer, A.; Wilson, C.H.; Tiffen, J.; Rust, A.G.; Stevens, P.; Idziaszczyk, S.; Maynard, J.; Williams, G.T.; Mustonen, V.; et al. Adenoma development in familial adenomatous polyposis and MUTYH-associated polyposis: Somatic landscape and driver genes. J. Pathol. 2016, 238, 98-108. [CrossRef]

45. Halazonetis, T.D.; Gorgoulis, V.G.; Bartek, J. An oncogene-induced DNA damage model for cancer development. Science 2008, 319, 1352-1355. [CrossRef]

46. Lefevre, J.H.; Colas, C.; Coulet, F.; Bonilla, C.; Mourra, N.; Flejou, J.F.; Tiret, E.; Bodmer, W.; Soubrier, F.; Parc, Y. MYH biallelic mutation can inactivate the two genetic pathways of colorectal cancer by APC or MLH1 transversions. Fam. Cancer 2010, 9 , 589-594. [CrossRef] [PubMed]

47. Morak, M.; Heidenreich, B.; Keller, G.; Hampel, H.; Laner, A.; de la Chapelle, A.; Holinski-Feder, E. Biallelic MUTYH mutations can mimic Lynch syndrome. Eur. J. Hum. Genet. 2014, 22, 1334-1337. [CrossRef] [PubMed]

48. Zachos, G.; Rainey, M.D.; Gillespie, D.A. Chk1-deficient tumour cells are viable but exhibit multiple checkpoint and survival defects. EMBO J. 2003, 22, 713-723. [CrossRef] [PubMed]

49. Kurman, R.J.; Shih, I.-M. The Dualistic model of ovarian carcinogenesis: Revisited, revised, and expanded. Am. J. Pathol. 2016, 186, 733-747. [CrossRef] [PubMed]

50. Knudson, A.G., Jr. Mutation and cancer: Statistical study of retinoblastoma. Proc. Natl. Acad. Sci. USA 1971, 68, 820-823. [CrossRef]

51. Armstrong, D.K.; Alvarez, R.D.; Bakkum-Gamez, J.N.; Barroilhet, L.; Behbakht, K.; Berchuck, K.; Berek, J.S.; Chen, L.-M.; Cristea, M.; DeRosa, M.; et al. National Comprehensive Cancer Network Clinical Practice Guidelines in Oncology: Ovarian Cancer Including Fallopian Tube Cancer and Primary Peritoneal Cancer. Version 1. 2020. Available online: https://www.nccn.org/ professionals / physician_gls/pdf/ovarian.pdf (accessed on 26 August 2020). 
52. Konstantinopoulos, P.A.; Lacchetti, C.; Annunziata, C.M. Germline and somatic tumor testing in epithelial ovarian cancer: ASCO guideline summary. JCO Oncol. Pract. 2020, 16, e835-e838. [CrossRef] [PubMed]

53. Casagrande, J.T.; Louie, E.W.; Pike, M.C.; Roy, S.; Ross, R.K.; Henderson, B.E. “Incessant ovulation” and ovarian cancer. Lancet 1979, 2, 170-173. [CrossRef]

54. Cramer, D.W.; Welch, W.R. Determinants of ovarian cancer risk. II. Inferences regarding pathogenesis. J. Natl. Cancer Inst. 1983, $71,717-721$.

55. Medeiros, F.; Muto, M.G.; Lee, Y.; Elvin, J.A.; Callahan, M.J.; Feltmate, C.; Garber, J.E.; Cramer, D.W.; Crum, C.P. The tubal fimbria is a preferred site for early adenocarcinoma in women with familial ovarian cancer syndrome. Am. J. Surg. Pathol. 2006, 30, 230-236. [CrossRef]

56. Testa, U.; Petrucci, E.; Pasquini, L.; Castelli, G.; Pelosi, E. Ovarian cancers: Genetic abnormalities, tumor heterogeneity and progression, clonal evolution and cancer stem cells. Medicines 2018, 5, 16. [CrossRef]

57. World Health Organization: International Agency for Research on Cancer. IARC Monographs on the Evaluation of Carcinogenic Risks to Humans. Internal Report 14/002: Report of the Advisory Group to Recommend Priorities for IARC Monographs during 2015-2019. Available online: https:/ / monographs.iarc.fr/wp-content/uploads/2018/08/14-002.pdf (accessed on 28 October 2020).

58. Pingarilho, M.; Oliveira, N.G.; Martins, C.; Fernandes, A.S.; de Lima, J.P.; Rueff, J.; Gaspar, J.F. Genetic polymorphisms in detoxification and DNA repair genes and susceptibility to glycidamide-induced DNA damage. J. Toxicol. Environ. Health A 2012, 75, 920-933. [CrossRef] [PubMed]

59. Nagata, C.; Konishi, K.; Tamura, T.; Wada, K.; Tsuji, M.; Hayashi, M.; Takeda, N.; Yasuda, K. Associations of acrylamide intake with circulating levels of sex hormones and prolactin in premenopausal Japanese women. Cancer Epidemiol. Biomarkers Prev. 2015, 24, 249-254. [CrossRef] [PubMed]

60. Yousef, M.I.; El-Demerdash, F.M. Acrylamide-induced oxidative stress and biochemical perturbations in rats. Toxicology 2006, 219, 133-141. [CrossRef] [PubMed]

61. Adani, G.; Filippini, T.; Wise, L.A.; Halldorsson, T.I.; Blaha, L.; Vinceti, M. Dietary intake of acrylamide and risk of breast, endometrial, and ovarian cancers: A systematic review and dose-response meta-analysis. Cancer Epidemiol. Biomark. Prev. 2020, 29, 1095-1106. [CrossRef] [PubMed]

62. Lee, Y.; Miron, A.; Drapkin, R.; Nucci, M.R.; Medeiros, F.; Saleemuddin, A.; Garber, J.; Birch, C.; Mou, H.; Gordon, R.W.; et al. A candidate precursor to serous carcinoma that originates in the distal fallopian tube. J. Pathol. 2007, 211, 26-35. [CrossRef] [PubMed]

63. Soong, T.R.; Howitt, B.E.; Miron, A.; Horowitz, N.S.; Campbell, F.; Feltmate, C.M.; Muto, M.G.; Berkowitz, R.S.; Nucci, M.R.; Xian, W.; et al. Evidence for lineage continuity between early serous proliferations (ESPs) in the Fallopian tube and disseminated high-grade serous carcinomas. J. Pathol. 2018, 246, 344-351. [CrossRef]

64. Clarke-Pearson, D.L. Clinical practice. Screening for ovarian cancer. N. Engl. J. Med. 2009, 361, 170-177. [CrossRef]

65. McLaughlin, J.R.; Risch, H.A.; Lubinski, J.; Moller, P.; Ghadirian, P.; Lynch, H.; Karlan, B.; Fishman, D.; Rosen, B.; Neuhausen, S.L.; et al. Reproductive risk factors for ovarian cancer in carriers of BRCA1 or BRCA2 mutations: A case-control study. Lancet Oncol. 2007, 8, 26-34. [CrossRef]

66. Michels, K.A.; Pfeiffer, R.M.; Brinton, L.A.; Trabert, B. Modification of the associations between duration of oral contraceptive use and ovarian, endometrial, breast, and colorectal cancers. JAMA Oncol. 2018, 4, 516-521. [CrossRef]

67. Daly, M.B.; Pal, T.; Berry, M.P.; Buys, S.S.; Dickson, P.; Domchek, S.M.; Elkhanany, A.; Friedman, S.; Goggins, M.; Hutton, M.L.; et al. National Comprehensive Cancer Network Clinical Practice Guidelines in Oncology: Genetic/Familial High-Risk Assessment: Breast, Ovarian, and Pancreatic. Version 2. 2021. Available online: https://www.nccn.org/professionals/physician_ gls/pdf/genetics_bop.pdf (accessed on 30 September 2020).

68. Skates, S.J.; Greene, M.H.; Buys, S.S.; Mai, P.L.; Brown, P.; Piedmonte, M.; Rodriguez, G.; Schorge, J.O.; Sherman, M.; Daly, M.B.; et al. Early detection of ovarian cancer using the Risk of Ovarian Cancer Algorithm with frequent CA125 testing in women at increased familial risk-Combined results from two screening trials. Clin. Cancer Res. 2017, 23, 3628-3637. [CrossRef]

69. Gaillard, S.L.; Bookman, M.A. Principles of chemotherapy in gynecologic cancer. In Principles and Practice of Gynecologic Oncology, 7th ed.; Chi, D.S., Berchuck, A., Dizon, D.S., Yashar, C., Eds.; Wolters Kluwer: Philadelphia, PA, USA, 2017 ; pp. $275-302$.

70. Galluzzi, L.; Senovilla, L.; Vitale, I.; Michels, J.; Martins, I.; Kepp, O.; Castedo, M.; Kroemer, G. Molecular mechanisms of cisplatin resistance. Oncogene 2012, 31, 1869-1883. [CrossRef] [PubMed]

71. Guo, Y.; Jia, Y.; Wang, S.; Liu, N.; Gao, D.; Zhang, L.; Lin, Z.; Wang, S.; Kong, F.; Peng, C.; et al. Downregulation of MUTYH contributes to cisplatin resistance of esophageal squamous cell carcinoma cells by promoting Twist mediated EMT. Oncol. Rep. 2019, 42, 2716-2727. [CrossRef] [PubMed]

72. Aebi, S.; Kurdi-Haidar, B.; Gordon, R.; Cenni, B.; Zheng, H.; Fink, D.; Christen, R.D.; Boland, C.R.; Koi, M.; Fishel, R.; et al. Loss of DNA mismatch repair in acquired resistance to cisplatin. Cancer Res. 1996, 56, 3087-3090. [PubMed]

73. Shibue, T.; Weinberg, R.A. EMT, CSCs, and drug resistance: The mechanistic link and clinical implications. Nat. Rev. Clin. Oncol. 2017, 14, 611-629. [CrossRef]

74. Chang, D.Y.; Lu, A.L. Interaction of checkpoint proteins Hus1/Rad1/Rad9 with DNA base excision repair enzyme MutY homolog in fission yeast, Schizosaccharomyces pombe. J. Biol. Chem. 2005, 280, 408-417. [CrossRef] 
75. Friedrich-Heineken, E.; Toueille, M.; Tännler, B.; Bürki, C.; Ferrari, E.; Hottiger, M.O.; Hübscher, U. The two DNA clamps Rad9/Rad1/Hus1 complex and proliferating cell nuclear antigen differentially regulate flap endonuclease 1 activity. J. Mol. Biol. 2005, 353, 980-989. [CrossRef]

76. Nguyen, T.T.; Chua, J.K.; Seah, K.S.; Koo, S.H.; Yee, J.Y.; Yang, E.G.; Lim, K.K.; Pang, S.Y.; Yuen, A.; Zhang, L.; et al. Predicting chemotherapeutic drug combinations through gene network profiling. Sci. Rep. 2016, 6, 18658. [CrossRef]

77. Cass, I.; Baldwin, R.L.; Varkey, T.; Moslehi, R.; Narod, S.A.; Karlan, B.Y. Improved survival in women with BRCA-associated ovarian carcinoma. Cancer 2003, 97, 2187-2195. [CrossRef]

78. Sakai, W.; Swisher, E.M.; Karlan, B.Y.; Agarwal, M.K.; Higgins, J.; Friedman, C.; Villegas, E.; Jacquemont, C.; Farrugia, D.J.; Couch, F.J.; et al. Secondary mutations as a mechanism of cisplatin resistance in BRCA2-mutated cancers. Nature 2008, 451, 1116-1120. [CrossRef]

79. Hussain, T.; Mulherkar, R. Lymphoblastoid cell lines: A continuous in vitro source of cells to study carcinogen sensitivity and DNA repair. Int. J. Mol. Cell Med. 2012, 1, 75-87.

80. Nielsen, M.; de Miranda, N.F.; van Puijenbroek, M.; Jordanova, E.S.; Middeldorp, A.; van Wezel, T.; van Eijk, R.; Tops, C.M.; Vasen, H.F.; Hes, F.J.; et al. Colorectal carcinomas in MUTYH-associated polyposis display histopathological similarities to microsatellite unstable carcinomas. BMC Cancer 2009, 9, 184. [CrossRef] [PubMed]

81. Xiao, X.; Dong, D.; He, W.; Song, L.; Wang, Q.; Yue, J.; Xie, L. Mismatch repair deficiency is associated with MSI phenotype, increased tumor-infiltrating lymphocytes and PD-L1 expression in immune cells in ovarian cancer. Gynecol. Oncol. 2018, 149, 146-154. [CrossRef] [PubMed]

82. Vaddepally, R.K.; Kharel, P.; Pandey, R.; Garje, R.; Chandra, A.B. Review of Indications of FDA-approved immune checkpoint inhibitors per NCCN guidelines with the level of evidence. Cancers 2020, 12, 738. [CrossRef] [PubMed]

83. Boland, P.M.; Yurgelun, M.B.; Boland, C.R. Recent progress in Lynch syndrome and other familial colorectal cancer syndromes CA Cancer J. Clin. 2018, 68, 217-231. [CrossRef]

84. Volkov, N.M.; Yanus, G.A.; Ivantsov, A.O.; Moiseenko, F.V.; Matorina, O.G.; Bizin, I.V.; Moiseyenko, V.M.; Imyanitov, E.N. Efficacy of immune checkpoint blockade in MUTYH-associated hereditary colorectal cancer. Investig. New Drugs 2020, 38, 894-898. [CrossRef]

85. Mouw, K.W.; Goldberg, M.S.; Konstantinopoulos, P.A.; D'Andrea, A.D. DNA damage and repair biomarkers of immunotherapy response. Cancer Discov. 2017, 7, 675-693. [CrossRef]

86. Huang, M.; Miao, Z.H.; Zhu, H.; Cai, Y.J.; Lu, W.; Ding, J. Chk1 and Chk2 are differentially involved in homologous recombination repair and cell cycle arrest in response to DNA double-strand breaks induced by camptothecins. Mol. Cancer Ther. 2008, 7, 1440-1449. [CrossRef]

87. de Bono, J.; Mateo, J.; Fizazi, K.; Saad, F.; Shore, N.; Sandhu, S.; Chi, K.N.; Sartor, O.; Agarwal, N.; Olmos, D.; et al. Olaparib for metastatic castration-resistant prostate cancer. N. Engl. J. Med. 2020, 382, 2091-2102. [CrossRef]

88. González-Martín, A.; Pothuri, B.; Vergote, I.; DePont Christensen, R.; Graybill, W.; Mirza, M.R.; McCormick, C.; Lorusso, D.; Hoskins, P.; Freyer, G.; et al. Niraparib in patients with newly diagnosed advanced ovarian cancer. N. Engl. J. Med. 2019, 381, 2391-2402. [CrossRef]

89. Amado, R.G.; Wolf, M.; Peeters, M.; Van Cutsem, E.; Siena, S.; Freeman, D.J.; Juan, T.; Sikorski, R.; Suggs, S.; Radinsky, R.; et al. Wild-type KRAS is required for panitumumab efficacy in patients with metastatic colorectal cancer. J. Clin. Oncol. 2008, 26, 1626-1634. [CrossRef]

90. Benson III, A.B.; Venook, A.P.; Al-Hawary, M.M.; Arain, M.A.; Chen, Y.-J.; Ciombor, K.K.; Cohen, S.; Cooper, H.S.; Deming, D.; Garrido-Laguna, I.; et al. National Comprehensive Cancer Network Clinical Practice Guidelines in Oncology: Colon Cancer. Version 4. 2020. Available online: https://www.nccn.org/professionals/physician_gls/pdf/colon.pdf (accessed on 30 October 2020).

91. Jänne, P.A.; Shaw, A.T.; Pereira, J.R.; Jeannin, G.; Vansteenkiste, J.; Barrios, C.; Franke, F.A.; Grinsted, L.; Zazulina, V.; Smith, P.; et al. Selumetinib plus docetaxel for KRAS-mutant advanced non-small-cell lung cancer: A randomised, multicentre, placebo-controlled, phase 2 study. Lancet Oncol. 2013, 14, 38-47. [CrossRef]

92. Nakayama, N.; Nakayama, K.; Yeasmin, S.; Ishibashi, M.; Katagiri, A.; Iida, K.; Fukumoto, M.; Miyazaki, K. KRAS or BRAF mutation status is a useful predictor of sensitivity to MEK inhibition in ovarian cancer. Br. J. Cancer 2008, 99, 2020-2028. [CrossRef] [PubMed]

93. Fujiwara, K.; McAlpine, J.N.; Lheureux, S.; Matsumura, N.; Oza, A.M. Paradigm Shift in the Management Strategy for Epithelial Ovarian Cancer. Am. Soc. Clin. Oncol. Educ. Book 2016, 35, e247-e257. [CrossRef] [PubMed] 